\title{
The Role of Hyperpolarization-Activated Cyclic Nucleotide-Gated Channels in the Pathophysiology of Absence Epilepsy
}

\section{Absans Epilepsisinin Patofizyolojisinde Hiperpolarizasyon Ille Aktive Olan Siklik Nükleotid Kapılı Kanalların (HCN) Rolü}

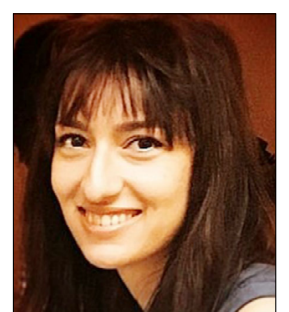

Dr. Melis YAVUZ

\section{(1) Melis YAVUZ, (1) Filiz ONAT}

Department of Medical Pharmacology, Marmara University Faculty of Medicine, İstanbul, Turkey

\section{Summary}

Hyperpolarization-activated cyclic nucleotide-gated ( $\mathrm{HCN})$ channels participate in pacemaker currents, modulating the funny current (I[f]) in cardiac cells and the hyperpolarization-activated current (I[h]) in neurons. Depending on the neuronal and synaptic localization, $\mathrm{HCN}$ channels regulate synaptic integration, long-term potentiation, synaptic transmission, and resting membrane potential. In summary, it contributes to the electrical activity between the excitatory and inhibitory stimuli through its shunting effect. Several second messengers modulate $\mathrm{I}(\mathrm{h})$ currents in the synapses by changing voltage-dependent activation kinetics. I(h) currents are being investigated in numerous central nervous system disorders, including epilepsy. On one hand, it is well known that I(h) currents lead to synchronized oscillations in the rhythmic burst mode in thalamocortical neurons underlying the pathophysiology of absence epilepsy. However, much of the evidence is contradictory. Therefore, it is important to understand the dynamic relationship of HCN channels within the oscillatory networks to determine the regional "queerness" of $\mathrm{I}(\mathrm{h})$, and we need further investigation to determine if upregulation or downregulation of $\mathrm{I}(\mathrm{h})$ is needed in order to suppress seizure activity.

Key words: Absence epilepsy; cyclic adenosine monophosphate; epilepsy; hyperpolarization-activated cyclic nucleotide-gated channels; I(f); I(h); ion channels; rat model; spike-and-wave discharge.

\section{Özet}

Hiperpolarizasyon ile aktive olan siklik nükleotid kapılı kanallar (HCN) pacemaker akımlara katılırlar ve kalpte If nöronlarda ise lh akımlarına aracılık ederler. Nöronal ve sinaptik yerleşimlerine göre, sinaptik entegrasyon, uzun dönemli potansiyalizasyon, sinaptik iletim ve dinlenim membran potansiyeli gibi faaliyetleri düzenlerler. Özetle, eksitatör ve inhibitör uyaranlar arasındaki elektriksel aktiviteye "şant etkisi" aracılığıyla katkıda bulunurlar. Bir takım ikinci haberciler, voltaja bağımlı aktivasyon kinetiklerini değiştirerek Ih akımlarını modüle ederler. Ih akımları epilepsi de dahil olmak üzere birçok merkezi sinir sistemi bozukluğunda incelenmektedir. Bir taraftan, Ih akımlarının absans epilepsisi patofizyolojisinin altında yatan mekanizma olan talamokortikal nöronlarda ritmik patlama modunda senkronize salınımlara yol açtığı iyi bilinmektedir. Ancak, elde edilen veriler birbiriyle çelişiyor görünmektedir. Bu nedenle, bu HCN kanallarının osilasyon şebekeleri içindeki dinamik ilişkisini anlamak, Ih akımlarının bölgeye özgü davranış kalıplarını anlamak ve nöbet aktivitesini baskılamak için temelde nasıl bir modülasyonunun gerektiğine karar vermek için daha fazla araştırmaya mı ihtiyacımız olduğu aşikardır.

Anahtar sözcükler: Absans epilepsisi; siklik adenozin monofosfat; epilepsi; hiperpolarizasyon ile aktive olan siklik nükleotid kapılı kanalları; If; Ih; iyon kanalları; sıçan modelleri; diken-ve-dalga deşarjları. 


\section{Introduction}

Hyperpolarization-activated cyclic nucleotide-gated (HCN) channels participate in pacemaker currents, ${ }^{[1]}$ mediating the funny current (I[f]) in cardiac cells and the hyperpolarizationactivated current (I[h]) in neurons. ${ }^{[2]}$ Early studies of the sinoatrial node (SAN) and Purkinje fibers date back to $1958^{[3]}$ and 1961. ${ }^{[4]} \mathrm{I}(\mathrm{h})$ and $\mathrm{I}(\mathrm{f})$ were later were studied in detail in the SAN ${ }^{[5]}$ hippocampal pyramidal neurons ${ }^{[6]}$ and rod photoreceptors. ${ }^{[7]}$ Subsequently, the genes encoding the expression of $\mathrm{HCN}$ channels in heterologous systems were identified. ${ }^{[8]}$

I(f) is called the funny current, assumed to be the result of the early German investigators directly translating "komisch," as "funny," which remains a common mistranslation even today, but it is better translated as "strange." The word "komisch" perfectly describes HCN channel characteristics. Instead of depolarization, I(h) channels are activated by hyperpolarization, and they reverse back at the potentials near depolarization. ${ }^{[9]}$ The I(h) current in neurons sets resting voltage levels and input resistance, adjusts the excitability and firing rates of the cell, and contributes to the electrical activity between the excitatory and inhibitory stimuli. ${ }^{[10]}$ Another quirk is the cyclic adenosine monophosphate (CAMP)-dependent activation of HCN channels as a voltage-gated ion channel. ${ }^{[2]}$

\section{Structure and Isoforms}

$\mathrm{HCN}$ channels are classified both in the category of voltage-gated $\mathrm{K}+$ channels and cyclic nucleotide-gated (CNG) channel classes. ${ }^{[11]} \mathrm{HCN}$ channels have 4 subunits around a central pore, consisting of 6 alpha-helical segments (S1S6). The ions are conducted through the loop between $\mathrm{S} 5$ and $\mathrm{S6}$. The voltage sensor is the $\mathrm{S} 4$ segment, which is positively charged..$^{[12]}$ During depolarization of the cell, the $\mathrm{S4}$ segment pushes $\mathrm{S} 5$ towards $\mathrm{S} 6$ and closes the pore. ${ }^{[13]}$ There is a cyclic nucleotide-binding domain (CNBD) connected to the $\mathrm{S} 6$ segment by a C-linker domain. CAMP binds here and shifts the activation of the HCN channels to the less negative potentials by discarding the basal inhibition of CNBD. ${ }^{[14]}$ CNBD has 6 interconnected helixes and forms a loop to enable the binding of CAMP. ${ }^{[15]}$ The weak selectivity for potassium over sodium seems to be related to the glycinetyrosine-glycine motif of the channel pore. ${ }^{[16]}$

HCN channels have 4 isoforms that exhibit different cAMP sensitivity, voltage characteristics, kinetics, and distribution.
[17] The selectivity of HCN for CAMP compared with other isoforms is related to the structural differences of CNBD in different isoforms. ${ }^{[18,19]}$ While HCN1 and HCN3 are less affected by CAMP, the opening kinetics of $\mathrm{HCN} 2$ and HCN4 depend more on CAMP. ${ }^{[8,14]}$ CAMP helps to increase the probability of channel opening by relieving the natural disinhibition caused by the conformation of CNBD. ${ }^{[20]}$ The higher CAMP sensitivity of $\mathrm{HCN} 2$ has been suggested to be due to certain amino acid residues in the $\mathrm{C}$-helix region of CNBD.

$\mathrm{HCN}$ channels are expressed throughout many cells. ${ }^{\left[{ }^{[21]}\right.} \mathrm{HCN} 1$ and $\mathrm{HCN} 2$ are predominantly expressed in the brain and the highest expression of $\mathrm{HCN} 2$ is in the thalamus and the brainstem nuclei. ${ }^{[22]} \mathrm{HCN} 2$ is also expressed in the SAN and the atrioventricular (AV) node in the heart. HCN3 is expressed mostly in the hypothalamus, olfactory bulb, heart muscle, liver, lung, and kidneys, and the highest expression was found to be in the embryonic stages. ${ }^{[2,24]} \mathrm{HCN} 4$ is expressed in the thalamus, ${ }^{[25]}$ basal ganglia, SAN, AV node, Purkinje, human testicles, skeletal muscle, and in the lungs (Table 1). ${ }^{[2,27]}$

\section{Neuronal Distribution of HCN Channels}

In general, the role of $\mathrm{HCN}$ channels in neurons comprises synaptic integration, long-term potentiation, synaptic transmission, control of working memory, motor learning, and resonance and oscillatory activities. ${ }^{[28]}$ The differential neuronal distribution of $\mathrm{HCN}$ channels became prominent when considering processes such as dendritic integration. In order to trigger an action potential, many excitatory postsynaptic potentials (EPSPS) must be gathered in the soma. ${ }^{[29]}$ It is thought that the greater accumulation of EPSPs in the soma on the distal site of the neuron rather than the proximal side may be due to temporal summation. But in turn, it is reduced in the distal more than the proximal due to condensed $\mathrm{I}(\mathrm{h})$ across the dendrite, where there is a 6-fold increase with distance from the soma. ${ }^{[30]}$ The blockade of HCN channels reduces excitability in the distal apical dendritic tufts, and therefore limits the distance dependence of EPSP summation. ${ }^{[31]}$ There is unequal distribution of $\mathrm{HCN}$ throughout the neuron to the proximal and distal sites by virtue of a shunting effect through the limitation in the activation of voltage-dependent calcium entry. ${ }^{[32]}$

The HCN isoforms at axon terminals have been shown to regulate vesicle release, such as regulating gamma-Aminobutyric acid(GABA) release pre-synaptically ${ }^{[33]}$ and glutamate release through voltage-gated T-type calcium 
Table 1. HCN channel isoforms

\begin{tabular}{|c|c|c|c|c|c|}
\hline HCN Isoforms & Regional Expression & Known Modulators & cAMP Sensitivity & Activation Speed & Activation Voltage \\
\hline HCN1 & $\begin{array}{c}\text { Cortex, hippocampus, cerebellum, } \\
\text { thalamus, DRG*, SAN, AV, } \\
\text { Purkinje fibers }\end{array}$ & $\begin{array}{l}\text { cGMP, PIP2, filaminA, } \\
\text { Nedd4-2, Thyl, pH }\end{array}$ & Low & $\begin{array}{l}\text { Fast activated; } \\
\text { 30-300 ms }\end{array}$ & $-70 \mathrm{mV}$ \\
\hline $\mathrm{HCN} 2$ & $\begin{array}{c}\text { Thalamus" and brain stem nuclei", } \\
\text { cortex hippocampus, cerebellum, } \\
\text { SAN, AV }\end{array}$ & $\begin{array}{l}\text { CGMP, PIP2, MiRP1, pH } \\
\text { tyrosine kinases }\end{array}$ & High & $\begin{array}{l}\text { Intermediate; } \\
\text { 200-400 ms }\end{array}$ & $-95 m V$ \\
\hline HCN3 & $\begin{array}{l}\text { Hypothalamus, olfactory bulb, } \\
\text { heart muscle, liver, lung, kidney }\end{array}$ & PIP2, pH & - & $\begin{array}{l}\text { Slow gating; } \\
400 \mathrm{~ms}-\mathrm{s}\end{array}$ & $(-77)-(-95) \mathrm{mV}$ \\
\hline $\mathrm{HCN} 4$ & $\begin{array}{c}\text { Thalamus, basal ganglia, SAN", AV", } \\
\text { Purkinje, human testicles, } \\
\text { skeletal muscle and the lung }\end{array}$ & $\begin{array}{c}\text { cGMP, PIP2, pH, tyrosine } \\
\text { kinases }\end{array}$ & High & $\begin{array}{l}\text { Slow gating; } \\
400 \text { ms-s }\end{array}$ & $-100 \mathrm{mV}$ \\
\hline
\end{tabular}

*Predominant form in a certain region. **Highest expression. AV: Atrioventricular node; CGMP: Cyclic guanosine monophosphate; DRG: Dorsal root ganglia; MiRP1: MinK-related protein; Nedd4-2: Neural precursor cell-expressed developmentally down-regulated protein 4-2; PIP2: Phosphatidylinositol 4,5-bisphosphate; SAN: Sinoatrial node; Thy1: A glycosylphosphatidylinositol-anchored protein.

(Ca[V]3.2) channels. ${ }^{[34]}$ The coupling of HCN channels to other proteins, such as histamine $\mathrm{H} 2$ receptors ${ }^{[35]}$ and $\mathrm{A}$ type potassium channels, has also been shown to regulate neuronal excitability. ${ }^{[36]}$

In summary, I(h) in the soma and proximal dendrites functions to depolarize and stabilize the resting membrane potential, and in distal dendrites, it decreases dendritic integration and limits dendritic calcium spikes. When expressed in axonal terminals, $\mathrm{l}(\mathrm{h})$ regulates GABA or glutamate release by enabling or disabling vesicles in different regions. ${ }^{[37]}$

\section{I(h) Currents and Activation Kinetics}

$\mathrm{HCN} 1$ is activated in less than 100 milliseconds and is isoform exhibiting the fastest activation. ${ }^{[38]} \mathrm{HCN} 2$ channels, on the other hand, have an activation time of around 200 to 400 milliseconds. ${ }^{[39]}$ While HCN4 and HCN3 have the slowest activation kinetics; they are activated within a range of 400 milliseconds to several seconds. ${ }^{[40]}$

Since HCN channels are activated by voltage, differences in the voltage-dependent activation of the isoforms are expected. In addition to the fast activation kinetics, it has been demonstrated that HCN1 is activated at voltages 20 $\mathrm{mV}$ more positive (less negative) than those needed for HCN2 channels. ${ }^{[14]}$ The CAMP response was greater in HCN2, which shifts the voltage levels around $20 \mathrm{mV}$ to more positive potentials. The exact voltage of activation can vary, but several studies have been performed to define a range: -70 $\mathrm{mV}$ for HCN1, $-95 \mathrm{mV}$ for HCN2, -77 to $95 \mathrm{mV}$ for HCN3, and $-100 \mathrm{mV}$ for HCN4 are the voltage levels in neurons when these isoforms are activated. ${ }^{[4]]}$
There is another interesting issue with the activation of $\mathrm{HCN}$ channels. In depolarized potentials, HCN channels activate at more negative voltages, but in more negative voltages, the voltage-dependent activation changes to more positive potentials. Basically, there is an intrinsic rhythm for $\mathrm{HCN}$ channels to act upon the electrical status quo and generate rhythmicity. This nature of acting upon the changes in stimulation is called the hysteresis concept. ${ }^{[42,43]}$

\section{Second Messengers and Modulation of HCN Channels}

The first second messenger found to modulate HCN channels was CAMP, which promotes the opening of the channels by shifting the activation kinetics to less hyperpolarized potentials, increasing the opening probability of the channels isoform dependently. ${ }^{[20]}$ cAMP binding seems to be regulated by auxiliary subunit tetratricopeptide repeatcontaining Rab8b-interacting protein (TRIP8b) and the Cterminal on the CNBD, accelerating activation and slowing deactivation. ${ }^{[44]}$ In particular, the co-assemblance of TRIP8b and $\mathrm{HCN}$ channels plays a role in the CAMP-dependent activation of $\mathrm{HCN} 2$ and $\mathrm{HCN} 4$ isoforms. ${ }^{[45]}$

Cyclic guanosine monophosphate (cGMP) has been shown to inhibit the gating of HCN2 channels with CGMP-dependent protein kinase II-mediated phosphorylation through a specific serine residue (S641) of the C-terminal end. ${ }^{[46]}$ HCN1, HCN2, and HCN4 isoforms have been shown to bind to CGMP with high affinity. ${ }^{[4]}$

While CAMP and voltage dependence are the key mechanisms for the regulation and modulation of HCN channels, several small molecules and ions also have an effect on the 
modulation of HCN channels. Phosphoinositides are among those modulators. Phosphatidylinositol 4,5-bisphosphate (PIP2) acts like CAMP in terms of shifting the activation to more depolarized levels but equally on isoforms, ${ }^{[48]}$ unlike CAMP $^{[49]}$ and the voltage shift seems to be a result of a distinct binding domain other than CNBD. ${ }^{[50]}$ Src kinases are also known to regulate channel activation positively in an isoform-dependent manner. ${ }^{[51]}$ Tyrosine phosphorylation activates $\mathrm{HCN} 2$ and $\mathrm{HCN} 4$ through the $\mathrm{CNBD}$ region. ${ }^{[52]}$ Another kinase, p38- mitogen-activated protein kinase (MAPK), has also been observed to have a modulatory function on $\mathrm{HCN}$ channels. ${ }^{\left[{ }^{[3]}\right]}$ Phosphatidic acid and arachidonic acid facilitate $\mathrm{HCN}$ gating by shifting the voltage activation 5 to $10 \mathrm{mV} .^{[54]}$

A gaseous neurotransmitter, nitric oxide, has been shown to reduce $\mathrm{I}(\mathrm{h})$ current by binding to cysteine residue and forming S-nitrosothiol complexes in the magnocellular neurosecretory cells of the supraoptic nucleus of rats. ${ }^{[5]}$

Several small proteins have been shown to interact with specific $\mathrm{HCN}$ isoforms: MinK-related proteins with $\mathrm{HCN} 2{ }^{[56]}$ filamin $A^{[57]}$ and neural precursor cell expressed developmentally down-regulated protein 4 (Nedd4-2) with $\mathrm{HCN1} 1{ }^{[58]}$ and thymus cell antigen 1 with HCN1 (Thy 1). ${ }^{[59]}$ Moreover, physiological $\mathrm{pH}$ plays a role in the modulation of $\mathrm{HCN}$ channels. Acidification of the inside of the cell has been demonstrated to inactivate $\mathrm{I}(\mathrm{h})$ in several studies. ${ }^{[60]}$

\section{HCN Channels and Pathophysiology}

Following the first findings of $\mathrm{I}(\mathrm{f})$ in the SAN of HCN channels, several dysfunctions of HCN channels were examined in cardiac myocytes, the SAN and pacemaker cells in animal models (1). ${ }^{[61-63]}$ In human studies, I(f) was isolated in heart failure patients and was found to be associated with cardiac hypertrophy. ${ }^{[64]}$ Congenital or acquired sick sinus syndrome, ${ }^{[28]}$ as well as bradycardia, ${ }^{[6]}$ and left ventricular cardiomyopathy were associated with mutations of HCN4. ${ }^{[66]}$ One interesting study shows HCN4 lacking the CNBD domain, which binds CAMP, had a reduced response to adrenergic stimuli. ${ }^{[67]}$ A recent human study also confirmed the results of this study, indicating that sinus tachycardia patients with a gain-of-function HCN4 mutation responded more to cAMP. ${ }^{[6]}$ To sum up, I(f) currents that gain functions seem to be underlying pro-arrhythmic potential and tachycardia. ${ }^{[69]}$ In line with these outcomes, biomechanical engineering of $\mathrm{HCN}$ channels seems to be a promising strategy in complete heart block pathologies. ${ }^{[70]}$
$\mathrm{HCN}$ dysfunction is related to several neuropsychiatric abnormalities. An association with schizophrenia has been reported in tHCN3 knockout (KO) mice. ${ }^{[71,72]}$ Positive modulation of $\mathrm{I}(\mathrm{h})$ currents seems to have a role in fear acquisition and has been associated with anxiety. ${ }^{[73]}$ Furthermore, dysfunction of HCN1 channels has been shown to correlate with depression, another neuropsychiatric condition. ${ }^{[7]}$

Neurodegenerative disorders, such as Parkinson's disease, ${ }^{[75]}$ amyotrophic lateral sclerosis, ${ }^{[76]}$ Alzheimer's disease, ${ }^{[7]}$ and epilepsy may be a result of an I(h) current imbalance. ${ }^{[7,79]}$ It makes sense, considering that the HCN channels set the neuronal firing pace, which is disrupted in epilepsy. It has been proposed that $\mathrm{SH} 3$ and multiple ankyrin repeat domains 3 (SHANK3) may increase the possibility of developing epilepsy ${ }^{[80]}$ and may also be associated with autism spectrum disorders, which have also been shown to be related to the function of HCN channels. ${ }^{[81]}$

Currently, the expression of HCN channels isoforms is also being investigated with regard to some peripheral nervous system pathologies, such as neuropathic pain. ${ }^{[82]}$ It was found that HCN1 and HCN2 were reduced in the left and right sciatic nerve in a rat neuropathic pain model; ${ }^{[83]}$ however, there was no change in the dorsal root ganglia (DRG), unlike other study findings that did indicated decreased HCN1 and HCN2 in the DRG. ${ }^{[82]}$ In addition to nervous system pathologies, $\mathrm{HCN} 1$ also seems to be associated with photoreceptor degeneration. ${ }^{[84]}$

\section{HCN and Epilepsies}

To take a quick look back at what $\mathrm{HCN}$ channels do in neurons would be a good start to investigating the role of these channels in epilepsy. First, HCN channels act as pacemakers, and in thalamocortical neurons, it has been shown that upon the generation of $\mathrm{Ca}++$ spikes, $\mathrm{HCN}$ channels are involved in the burst action potentials. ${ }^{[85]}$ Secondly, in dendritic synapses, I(h) has a shunt mechanism that paces EPSP amplitude and duration and limits temporal summation. ${ }^{[86,87]}$ The abnormal regulation of I(h) in layer III cortical neurons, the neocortex, CA1 pyramidal neurons, and thalamocortical neurons are a few examples of regions associated with seizure generation. ${ }^{[88-90]}$

Temporal lobe epilepsy ${ }^{[01,92]}$ and absence epilepsy rat models have been well-studied with respect to I( $h$ ) current modulation. ${ }^{[93-96]} I(\mathrm{~h})$ disruption has also been reported in a ro- 
dent febrile seizure model. ${ }^{[97]} \mathrm{HCN} 1$ and HCN2 are among the isoforms that are related to genetic epilepsies in humans. ${ }^{[98]}$

There are several studies that associate HCN channel expressions with epileptogenesis. In a pilocarpine model, dendritic HCN1 and HCN2 channels were downregulated, and in the chronic period it was reported that expression re-increased when epilepsy was established. ${ }^{\left[{ }^{11]}\right.}$ In different seizure models, $\mathrm{I}(\mathrm{h})$ imbalance varied according to the region. ${ }^{[97]}$ The differential regulation of $\mathrm{I}(\mathrm{h})$ in different seizure models may imply that a region-specific density of I(h) may serve various purposes in epileptogenesis and maybe even seizure protection/resistance dynamics.

\section{HCN Channels in the Pathophysiology of Absence Epilepsy}

Rhythmicity in the cortico-thalamo-cortical network, like sleep spindles and spike-and-wave discharges (SWD), which are delta activity, are thalamo-cortical oscillations that are modulated by hyperpolarization regulated by $\mathrm{I}(\mathrm{h}) .^{[99]}$

I(h) currents lead to synchronized oscillations in the rhythmic burst mode, ${ }^{[85]}$ creating pacemaker potentials with low-threshold $\mathrm{Ca}++$ currents in the thalamic relay cells. The relationship between $\mathrm{HCN}$ channel function and absence epilepsy pathogenesis has been shown most specifically in HCN2 KO mice, ${ }^{[96]}$ which had decreased HCN channel activity and exhibited synchronized bilateral SWD activity, a hallmark of absence epilepsy on an electroencephalogram. This activity was characterized by abnormal rhythmic activity resulting in increased hyperpolarization in the thalamocortical loop. The thalamocortical neurons of HCN2 KO mice exhibited increased burst firing with decreased I(h) current density, and the neurons were more hyperpolarized. Subsequent study results supported the association between negative modulation of $\mathrm{I}(\mathrm{h})$ and seizure production with the coding of a mutation in the TRIP8b HCN2 channel subunit. ${ }^{[100,101]}$

Experimental rat model studies using subjects with chronic absence epilepsy, Genetic Absence Epilepsy Rats from Strasbourg (GAERS), and Wistar Albino Glaxo/Rijswik (WAG/ Rij) rats, also revealed the role of HCN channels in the pathophysiology of SWDs. ${ }^{[102]} \mathrm{HCN} 1$ expression and I(h) currents in the cortical neurons of WAG/Rij mice have been shown to be significantly reduced. ${ }^{[103]}$ In addition to the quantity of $I(h)$ currents, the sensitivity of these currents to CAMP has also been shown to play a role in the pathogenesis of

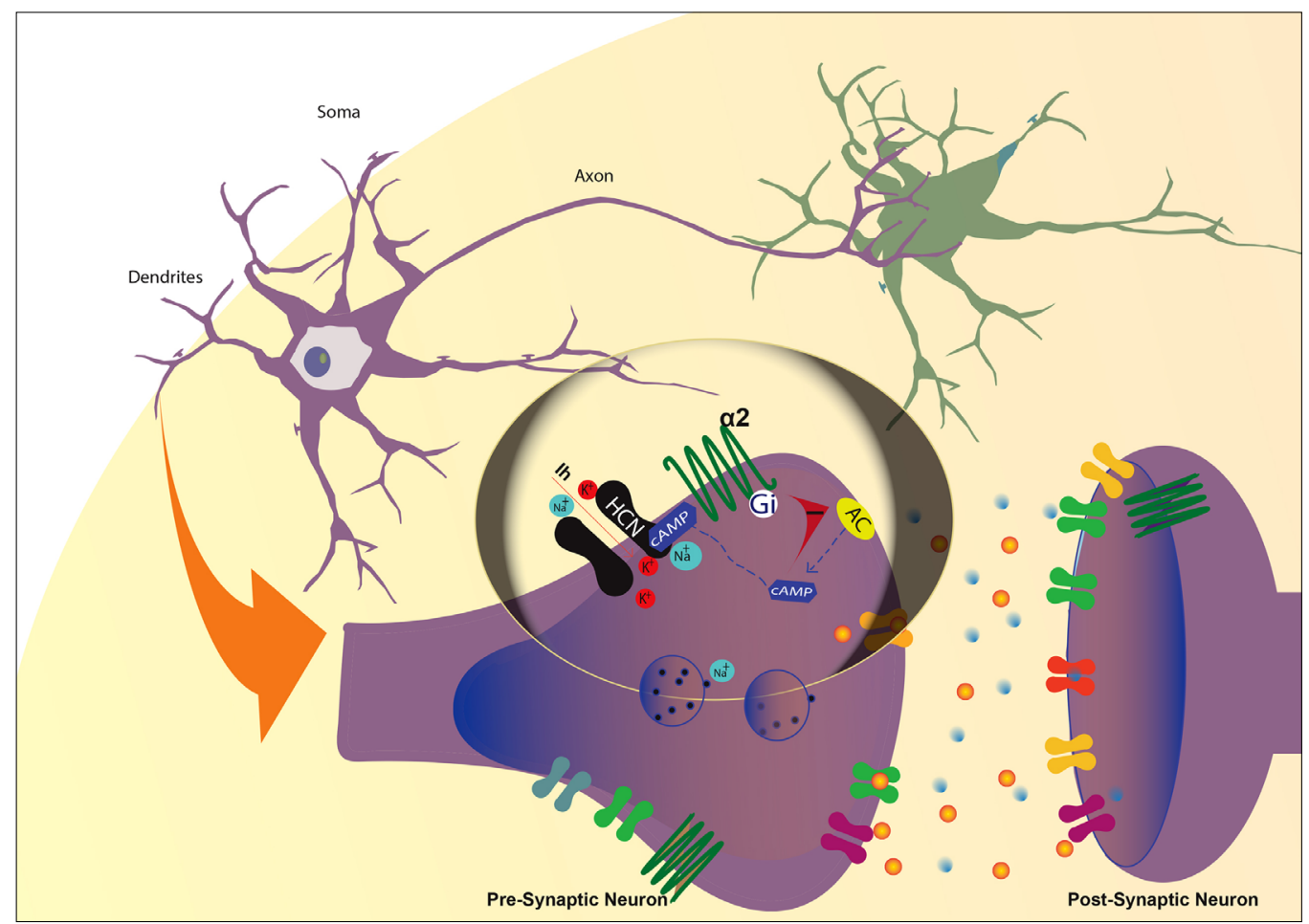

Fig. 1. HCN channels on dendrites. 
absence epilepsy ${ }^{[89]}$ In WAG/Rij and GAERS strains, the sensitivity of thalamic I(h) currents to CAMP was demonstrated to be lower, and consequently, the expression of HCN1 was increased in thalamus by intracellular cAMP increases. ${ }^{[95]}$ In GAERS specimens, HCN2 and HCN4 isoforms did not seem to change in thalamic reticular neurons (Rtn) or the ventral posteromedial nucleus (Vpm) of the thalamus, but the cAMP insensitive isoform HCN1 was enhanced in the Vpm and the Rtn thalamus. ${ }^{[95]}$

The inhibition of $\mathrm{I}(\mathrm{h})$ is thought to shift the activation kinetics to more hyperpolarized potentials, where the shift from tonic to burst-firing mode occurs. ${ }^{[96]}$ But a study did not find that much-expected increase in SWD during the application of an I(h) blocker, ORG34167. Indeed, intracortical administration resulted in SWD suppression. ${ }^{[104]}$ I(h) blocking in the ventrobasal thalamus was observed to suppress burst firing in those neurons. ${ }^{[105]} \mathrm{I}(\mathrm{h})$ seems to be reduced in the neocortical neurons, while in the thalamocortical neurons, it may be either increased or remain unchanged in epilepsy. ${ }^{[105]}$ The contradictory data regarding I( $h$ ) need further investigation in different brain regions.

\section{Future Perspectives}

Substantial work will be necessary to fully observe and understand the modulation of $\mathrm{I}(\mathrm{h})$ currents and the phenotype it expresses in single networks. The global inhibition of $\mathrm{I}(\mathrm{h})$ as a treatment strategy seems to fail, according to many studies. global $\mathrm{I}(\mathrm{h})$ agonism looks more promising in terms of SWD suppression, considering that the cortex plays a major role in expressing the SWD phenotype and is where $\mathrm{I}(\mathrm{h})$ currents are downregulated in absence epilepsy phenotypes.

Blocking I(h) has been shown to decrease delta oscillations, ${ }^{[106]}$ and to reduce delta sleep. $\left.{ }^{[107,108]}\right]$ (h)-mediated delta and theta resonances obtained in hippocampal interneurons and pyramidal cells under identical experimental conditions had different outcomes. ${ }^{[109]}$ Therefore, neuronal distribution, synaptic localization, and co-localization of $\mathrm{HCN}$ channels with other proteins should be investigated to find what exactly caused these different outcomes.

Since the presence of delta frequencies with other thalamocortical oscillations such as SWDs is seen as necessary, ${ }^{[110]}$ the concept of vigilance comes forward. ${ }^{[111]}$ An alpha-adrenergic blocker has been shown to decrease the delta fre- quency in the cortex and in the Vpm..$^{[107]}$ The net effect on delta oscillations may be a result of a rise in CAMP concentrations that increases $\mathrm{I}(\mathrm{h})$, which strengthens the possible co-work of HCN channels and alpha adrenergic receptors. Therefore, it is important to investigate the interaction between the alpha adrenergic receptor and HCN, particularly considering their co-localization in certain brain regions (See Fig. 1).

Casting the more basic science side of the concept to the side, many antiepileptic drugs seem to be modulating I(h) currents now. Lamotrigine, ${ }^{[112]}$ gabapentin, ${ }^{[113]}$ acetazolamide ${ }^{[60]}$ and ethosuximide have been demonstrated to increase I(h) currents. ${ }^{[114]}$ Current medications that inhibit SWDs can be investigated for further mechanisms of action, especially T-type channel blocking agents that block SWDs.

The concept that there is a single mechanism of action in pharmacology seems to be due for a change. The calculation of the combined or net effect of any antiepileptic agent with other factors could be a key to the future, especially considering the differential net effects of global funny currents.

\section{References}

1. DiFrancesco D. Pacemaker mechanisms in cardiac tissue. Annu Rev Physiol 1993;55:455-2. [CrossRef]

2. DiFrancesco D, Tortora P. Direct activation of cardiac pacemaker channels by intracellular cyclic AMP. Nature 1991;351(6322):145-7. [CrossRef]

3. Dudel J, Trautwein W. The mechanism of formation of automatic rhythmical impulses in heart muscle [Article in German]. Pflugers Arch Gesamte Physiol Menschen Tiere 1958;267(6):553-65. [CrossRef]

4. Trautwein W, Kassebaum DG. On the mechanism of spontaneous impulse generation in the pacemaker of the heart. J Gen Physiol 1961;45:317-30. [CrossRef]

5. Brown H, Difrancesco D, Noble S. Cardiac pacemaker oscillation and its modulation by autonomic transmitters. J Exp Biol 1979;81:175-204.

6. Halliwell JV, Adams PR. Voltage-clamp analysis of muscarinic excitation in hippocampal neurons. Brain Res 1982;250(1):71-92.

7. Bader CR, Macleish PR, Schwartz EA. A voltage-clamp study of the light response in solitary rods of the tiger salamander. $J$ Physiol 1979;296:1-26. [CrossRef]

8. Seifert R, Scholten A, Gauss R, Mincheva A, Lichter P, Kaupp UB. Molecular characterization of a slowly gating human 
hyperpolarization-activated channel predominantly expressed in thalamus, heart, and testis. Proc Natl Acad Sci USA 1999;96(16):9391-6. [CrossRef]

9. Santoro B, Baram TZ. The multiple personalities of $\mathrm{h}$-channels. Trends Neurosci 2003;26(10):550-4. [CrossRef]

10. Luthi A, Bal T, McCormick DA. Periodicity of thalamic spindle waves is abolished by ZD7288,a blocker of Ih. J Neurophysiol 1998;79(6):3284-9. [CrossRef]

11. Hofmann F, Biel M, Kaupp UB. International Union of Pharmacology. LI. Nomenclature and structure-function relationships of cyclic nucleotide-regulated channels. Pharmacol Rev 2005;57(4):455-62. [CrossRef]

12. Yu FH, Catterall WA. The VGL-chanome: a protein superfamily specialized for electrical signaling and ionic homeostasis. Sci STKE 2004;2004(253):re15. [CrossRef]

13. Männikkö R, Elinder F, Larsson HP. Voltage-sensing mechanism is conserved among ion channels gated by opposite voltages. Nature 2002;419(6909):837-41. [CrossRef]

14. Wainger BJ, DeGennaro M, Santoro B, Siegelbaum SA, Tibbs GR. Molecular mechanism of CAMP modulation of HCN pacemaker channels. Nature 2001;411(6839):805-10. [CrossRef]

15. Wang J, Chen S, Siegelbaum SA. Regulation of hyperpolarization-activated $\mathrm{HCN}$ channel gating and CAMP modulation due to interactions of $\mathrm{COOH}$ terminus and core transmembrane regions. J Gen Physiol 2001;118(3):237-50. [CrossRef]

16. Xue T, Marbán E, Li RA. Dominant-negative suppression of HCN1- and HCN2-encoded pacemaker currents by an engineered HCN1 construct: insights into structure-function relationships and multimerization. Circ Res 2002;90(12):1267-73.

17. Ludwig A, Zong X, Jeglitsch M, Hofmann F, Biel M. A family of hyperpolarization-activated mammalian cation channels. $\mathrm{Na}$ ture. 1998;393(6685):587-91. [CrossRef]

18. Brelidze TI, Carlson AE, Zagotta WN. Absence of direct cyclic nucleotide modulation of MEAG1 and hERG1 channels revealed with fluorescence and electrophysiological methods. J Biol Chem. 2009;284(41):27989-97. [CrossRef]

19. Lolicato M, Nardini M, Gazzarrini S, Moller S, Bertinetti D, Herberg FW, et al. Tetramerization dynamics of C-terminal domain underlies isoform-specific cAMP gating in hyperpolarization-activated cyclic nucleotide-gated channels. J Biol Chem. 2011;286(52):44811-20. [CrossRef]

20. Thon S, Schmauder R, Benndorf K. Elementary functional properties of single HCN2 channels. Biophys J 2013;105(7):1581-9.

21. Brewster AL, Chen Y, Bender RA, Yeh A, Shigemoto R, Baram TZ. Quantitative analysis and subcellular distribution of mRNA and protein expression of the hyperpolarization-activated cyclic nucleotide-gated channels throughout development in rat hippocampus. Cereb Cortex 2007;17(3):702-12. [CrossRef]
22. Santoro B, Chen S, Luthi A, Pavlidis P, Shumyatsky GP, Tibbs GR, et al. Molecular and functional heterogeneity of hyperpolarization-activated pacemaker channels in the mouse CNS. J Neurosci 2000;20(14):5264-75. [CrossRef]

23. Moosmang S, Biel M, Hofmann F, Ludwig A. Differential distribution of four hyperpolarization-activated cation channels in mouse brain. Biol Chem 1999;380(7-8):975-80. [CrossRef]

24. Schweizer PA, Yampolsky P, Malik R, Thomas D, Zehelein J, Katus HA, et al. Transcription profiling of HCN-channel isotypes throughout mouse cardiac development. Basic Res Cardiol 2009;104(6):621-9. [CrossRef]

25. Abbas SY, Ying SW, Goldstein PA. Compartmental distribution of hyperpolarization-activated cyclic-nucleotide-gated channel 2 and hyperpolarization-activated cyclic-nucleotide-gated channel 4 in thalamic reticular and thalamocortical relay neurons. Neuroscience 2006;141(4):1811-25. [CrossRef]

26. Herrmann S, Schnorr S, Ludwig A. HCN channels-modulators of cardiac and neuronal excitability. Int J Mol Sci 2015;16(1):142947. [CrossRef]

27. Postea O, Biel M. Exploring HCN channels as novel drug targets. Nat Rev Drug Discov 2011;10(12):903-14. [CrossRef]

28. Biel M, Wahl-Schott C, Michalakis S, Zong X. Hyperpolarizationactivated cation channels: from genes to function. Physiol Rev 2009;89(3):847-85. [CrossRef]

29. Axmacher N, Miles R. Intrinsic cellular currents and the temporal precision of EPSP-action potential coupling in CA1 pyramidal cells. J Physiol 2004;555(Pt 3):713-25. [CrossRef]

30. Magee JC. Dendritic integration of excitatory synaptic input. Nat Rev Neurosci 2000;1(3):181-90. [CrossRef]

31. Williams SR, Stuart GJ. Site independence of EPSP time course is mediated by dendritic $\mathrm{I}(\mathrm{h})$ in neocortical pyramidal neurons. J Neurophysiol 2000;83(5):3177-82. [CrossRef]

32. Tsay $D$, Yuste R. On the electrical function of dendritic spines. Trends Neurosci 2004;27(2):77-83. [CrossRef]

33. Boyes J, Bolam JP, Shigemoto R, Stanford IM. Functional presynaptic HCN channels in the rat globus pallidus. Eur J Neurosci 2007;25(7):2081-92. [CrossRef]

34. Huang Z, Lujan R, Kadurin I, Uebele VN, Renger JJ, Dolphin AC, et al. Presynaptic HCN1 channels regulate Cav3.2 activity and neurotransmission at select cortical synapses. Nat Neurosci 2011;14(4):478-86. [CrossRef]

35. Li B, Zhang XY, Yang AH, Peng XC, Chen ZP, Zhou JY, et al. Histamine Increases Neuronal Excitability and Sensitivity of the Lateral Vestibular Nucleus and Promotes Motor Behaviors via HCN Channel Coupled to H2 Receptor. Front Cell Neurosci 2016;10:300.

36. Mishra P, Narayanan R. High-conductance states and A-type $\mathrm{K}+$ channels are potential regulators of the conductance- 
current balance triggered by HCN channels. J Neurophysiol 2015;113(1):23-43. [CrossRef]

37. He C, Chen F, Li B, Hu Z. Neurophysiology of HCN channels: from cellular functions to multiple regulations. Prog Neurobiol 2014;112:1-23. [CrossRef]

38. Azene EM, Xue T, Marbán E, Tomaselli GF, Li RA. Non-equilibrium behavior of $\mathrm{HCN}$ channels: insights into the role of $\mathrm{HCN}$ channels in native and engineered pacemakers. Cardiovasc Res 2005;67(2):263-73. [CrossRef]

39. Ludwig A, Zong X, Stieber J, Hullin R, Hofmann F, Biel M. Two pacemaker channels from human heart with profoundly different activation kinetics. EMBO J 1999;18(9):2323-9. [CrossRef]

40. Mistrik $P$, Mader R, Michalakis S, Weidinger M, Pfeifer A, Biel $M$. The murine HCN3 gene encodes a hyperpolarization-activated cation channel with slow kinetics and unique response to cyclic nucleotides. J Biol Chem 2005;280(29):27056-61.

41. Wahl-Schott C, Biel M. HCN channels: structure, cellular regulation and physiological function. Cell Mol Life Sci 2009;66(3):470-94. [CrossRef]

42. Bruening-Wright A, Larsson HP. Slow conformational changes of the voltage sensor during the mode shift in hyperpolarization-activated cyclic-nucleotide-gated channels. J Neurosci 2007;27(2):270-8. [CrossRef]

43. Männikkö R, Pandey S, Larsson HP, Elinder F. Hysteresis in the voltage dependence of $\mathrm{HCN}$ channels: conversion between two modes affects pacemaker properties. J Gen Physiol 2005;125(3):305-26. [CrossRef]

44. Wicks NL, Wong T, Sun J, Madden Z, Young EC. Cytoplasmic CAMP-sensing domain of hyperpolarization-activated cation (HCN) channels uses two structurally distinct mechanisms to regulate voltage gating. Proc Natl Acad Sci USA 2011;108(2):609-14. [CrossRef]

45. Zolles G, Wenzel D, Bildl W, Schulte U, Hofmann A, Müller CS, et al. Association with the auxiliary subunit PEX5R/Trip8b controls responsiveness of HCN channels to CAMP and adrenergic stimulation. Neuron 2009;62(6):814-25. [CrossRef]

46. Hammelmann V, Zong X, Hofmann F, Michalakis S, Biel M. The cGMP-dependent protein kinase II Is an inhibitory modulator of the hyperpolarization-activated HCN2 channel. PLoS One 2011;6(2):e17078. [CrossRef]

47. Moller S, Alfieri A, Bertinetti D, Aquila M, Schwede F, Lolicato $M$, et al. Cyclic nucleotide mapping of hyperpolarization-activated cyclic nucleotide-gated (HCN) channels. ACS Chem Biol 2014;9(5):1128-37. [CrossRef]

48. Pian P, Bucchi A, Decostanzo A, Robinson RB, Siegelbaum SA. Modulation of cyclic nucleotide-regulated $\mathrm{HCN}$ channels by PIP(2) and receptors coupled to phospholipase C. Pflugers Arch 2007;455(1):125-45. [CrossRef]
49. Ying SW, Tibbs GR, Picollo A, Abbas SY, Sanford RL, Accardi A, et al. PIP2-mediated HCN3 channel gating is crucial for rhythmic burst firing in thalamic intergeniculate leaflet neurons. J Neurosci 2011;31(28):10412-23. [CrossRef]

50. Flynn GE, Zagotta WN. Molecular mechanism underlying phosphatidylinositol 4,5-bisphosphate-induced inhibition of SplH channels. J Biol Chem 2011;286(17):15535-42. [CrossRef]

51. Zong $X$, Eckert $C$, Yuan $H$, Wahl-Schott $C$, Abicht $H$, Fang L, et al. A novel mechanism of modulation of hyperpolarization-activated cyclic nucleotide-gated channels by Src kinase. J Biol Chem. 2005;280(40):34224-32. [CrossRef]

52. Yu HG, Lu Z, Pan Z, Cohen IS. Tyrosine kinase inhibition differentially regulates heterologously expressed $\mathrm{HCN}$ channels. Pflugers Arch 2004;447(4):392-400. [CrossRef]

53. Poolos NP, Bullis JB, Roth MK. Modulation of h-channels in hippocampal pyramidal neurons by $\mathrm{p} 38$ mitogen-activated protein kinase. J Neurosci 2006;26(30):7995-8003. [CrossRef]

54. Fogle KJ, Lyashchenko AK, Turbendian HK, Tibbs GR. HCN pacemaker channel activation is controlled by acidic lipids downstream of diacylglycerol kinase and phospholipase A2. J Neurosci 2007;27(11):2802-14. [CrossRef]

55. Pires da Silva $M$, de Almeida Moraes DJ, Mecawi AS, Rodrigues JA, Varanda WA. Nitric Oxide Modulates HCN Channels in Magnocellular Neurons of the Supraoptic Nucleus of Rats by an S-Nitrosylation-Dependent Mechanism. J Neurosci 2016;36(44):11320-30. [CrossRef]

56. Qu J, Kryukova Y, Potapova IA, Doronin SV, Larsen M, Krishnamurthy G, et al. MiRP1 modulates HCN2 channel expression and gating in cardiac myocytes. J Biol Chem 2004;279(42):43497502. [CrossRef]

57. Gravante B, Barbuti A, Milanesi R, Zappi I, Viscomi C, DiFrancesco D. Interaction of the pacemaker channel HCN1 with filamin A. J Biol Chem. 2004;279(42):43847-53. [CrossRef]

58. Wilkars W, Wollberg J, Mohr E, Han M, Chetkovich DM, Bahring $\mathrm{R}$, et al. Nedd4-2 regulates surface expression and may affect $\mathrm{N}$ glycosylation of hyperpolarization-activated cyclic nucleotidegated (HCN)-1 channels. FASEB J 2014;28(5):2177-90. [CrossRef]

59. Partida GJ, Stradleigh TW, Ogata G, Godzdanker I, Ishida AT. Thy 1 associates with the cation channel subunit HCN4 in adult rat retina. Invest Ophthalmol Vis Sci 2012;53(3):1696-703.

60. Munsch T, Pape HC. Modulation of the hyperpolarization-activated cation current of rat thalamic relay neurones by intracellular pH. J Physiol 1999;519 Pt 2:493-504. [CrossRef]

61. Huang $X$, Yang P, Du Y, Zhang J, Ma A. Age-related down-regulation of HCN channels in rat sinoatrial node. Basic Res Cardiol 2007;102(5):429-35. [CrossRef]

62. Verkerk AO, Wilders R. Pacemaker activity of the human sinoatrial node: an update on the effects of mutations in HCN4 
on the hyperpolarization-activated current. Int J Mol Sci 2015;16(2):3071-94. [CrossRef]

63. Zicha S, Fernandez-Velasco M, Lonardo G, L'Heureux N, Nattel S. Sinus node dysfunction and hyperpolarization-activated (HCN) channel subunit remodeling in a canine heart failure model. Cardiovasc Res 2005;66(3):472-81. [CrossRef]

64. Cerbai E, Pino R, Porciatti F, Sani G, Toscano M, Maccherini M, et al. Characterization of the hyperpolarization-activated current, I(f), in ventricular myocytes from human failing heart. Circulation 1997;95(3):568-71. [CrossRef]

65. Baruscotti M, Bottelli G, Milanesi R, DiFrancesco JC, DiFrancesco D. HCN-related channelopathies. Pflugers Arch 2010;460(2):405-15. [CrossRef]

66. Milano A, Vermeer AM, Lodder EM, Barc J, Verkerk AO, Postma $\mathrm{AV}$, et al. HCN4 mutations in multiple families with bradycardia and left ventricular noncompaction cardiomyopathy. J Am Coll Cardiol 2014;64(8):745-56. [CrossRef]

67. Alig J, Marger L, Mesirca P, Ehmke H, Mangoni ME, Isbrandt D. Control of heart rate by CAMP sensitivity of HCN channels. Proc Natl Acad Sci USA 2009;106(29):12189-94. [CrossRef]

68. Baruscotti M, Bucchi A, Milanesi R, Paina M, Barbuti A, Gnecchi-Ruscone T, et al. A gain-of-function mutation in the cardiac pacemaker HCN4 channel increasing CAMP sensitivity is associated with familial Inappropriate Sinus Tachycardia. Eur Heart J 2017;38(4):280-8. [CrossRef]

69. Kuwabara Y, Kuwahara K, Takano M, Kinoshita H, Arai Y, Yasuno $\mathrm{S}$, et al. Increased expression of HCN channels in the ventricular myocardium contributes to enhanced arrhythmicity in mouse failing hearts. J Am Heart Assoc 2013;2(3):e000150. [CrossRef]

70. Chan PKW, Geng L, Gao Y, Keung W, Li RA. AAV-mediated conversion of human pluripotent stem cell-derived pacemaker. Biochem Biophys Res Commun 2017;494(1-2):346-51. [CrossRef]

71. Stieglitz MS, Fenske S, Hammelmann V, Becirovic E, Schöttle V, Delorme JE, et al. Disturbed Processing of Contextual Information in HCN3 Channel Deficient Mice. Front Mol Neurosci 2018;10:436. [CrossRef]

72. Arnsten AF, Casey BJ. Prefrontal cortical organization and function: implications for externalizing disorders. Biol Psychiatry 2011;69(12):1131-2. [CrossRef]

73. Knoll AT, Halladay LR, Holmes AJ, Levitt P. Quantitative Trait Loci and a Novel Genetic Candidate for Fear Learning. J Neurosci 2016;36(23):6258-68. [CrossRef]

74. Kim CS, Chang PY, Johnston D. Enhancement of dorsal hippocampal activity by knockdown of HCN1 channels leads to anxiolytic- and antidepressant-like behaviors. Neuron 2012;75(3):503-16. [CrossRef]

75. Masi A, Narducci R, Resta F, Carbone C, Kobayashi K, Mannaioni G. Differential contribution of $\mathrm{Ih}$ to the integration of excita- tory synaptic inputs in substantia nigra pars compacta and ventral tegmental area dopaminergic neurons. Eur J Neurosci 2015;42(9):2699-706. [CrossRef]

76. Bellingham MC. Pre- and postsynaptic mechanisms underlying inhibition of hypoglossal motor neuron excitability by riluzole. J Neurophysiol 2013;110(5):1047-61. [CrossRef]

77. Saito $Y$, Inoue $T$, Zhu G, Kimura N, Okada M, Nishimura $M$, et al. Hyperpolarization-activated cyclic nucleotide gated channels: a potential molecular link between epileptic seizures and $A \beta$ generation in Alzheimer's disease. Mol Neurodegener 2012;7:50. [CrossRef]

78. Nava C, Dalle C, Rastetter A, Striano P, de Kovel CG, Nabbout R, et al. De novo mutations in HCN1 cause early infantile epileptic encephalopathy. Nat Genet 2014;46(6):640-5. [CrossRef]

79. Kanyshkova T, Meuth P, Bista P, Liu Z, Ehling P, Caputi L, et al. Differential regulation of $\mathrm{HCN}$ channel isoform expression in thalamic neurons of epileptic and non-epileptic rat strains. Neurobiol Dis 2012;45(1):450-61. [CrossRef]

80. Holder JL Jr, Quach MM. The spectrum of epilepsy and electroencephalographic abnormalities due to SHANK3 loss-offunction mutations. Epilepsia 2016;57(10):1651-9. [CrossRef]

81. Yi F, Danko T, Botelho SC, Patzke C, Pak C, Wernig M, et al. Autism-associated SHANK3 haploinsufficiency causes Ih channelopathy in human neurons. Science 2016;352(6286):aaf2669.

82. Chaplan SR, Guo HQ, Lee DH, Luo L, Liu C, Kuei C, et al. Neuronal hyperpolarization-activated pacemaker channels drive neuropathic pain. J Neurosci 2003;23(4):1169-78. [CrossRef]

83. Liu H, Zhou J, Gu L, Zuo Y. The change of HCN1/HCN2 mRNA expression in peripheral nerve after chronic constriction injury induced neuropathy followed by pulsed electromagnetic field therapy. Oncotarget 2017;8(1):1110-6. [CrossRef]

84. Schon C, Asteriti S, Koch S, Sothilingam V, Garcia Garrido M, Tanimoto $\mathrm{N}$, et al. Loss of HCN1 enhances disease progression in mouse models of CNG channel-linked retinitis pigmentosa and achromatopsia. Hum Mol Genet 2016;25(6):1165-75. [CrossRef]

85. Pape HC. Queer current and pacemaker: the hyperpolarization-activated cation current in neurons. Annu Rev Physiol 1996;58:299-327. [CrossRef]

86. Magee JC. Dendritic hyperpolarization-activated currents modify the integrative properties of hippocampal CA1 pyramidal neurons. J Neurosci 1998;18(19):7613-24. [CrossRef]

87. Magee JC. Dendritic Ih normalizes temporal summation in hippocampal CA1 neurons. Nat Neurosci 1999;2(9):848. [CrossRef]

88. Brewster A, Bender RA, Chen Y, Dube C, Eghbal-Ahmadi M, Baram TZ. Developmental febrile seizures modulate hippocampal gene expression of hyperpolarization-activated channels in an isoform- and cell-specific manner. J Neurosci 2002;22(11):4591-9. [CrossRef] 
89. Budde T, Caputi L, Kanyshkova T, Staak R, Abrahamczik C, Munsch T, et al. Impaired regulation of thalamic pacemaker channels through an imbalance of subunit expression in absence epilepsy. J Neurosci 2005;25(43):9871-82. [CrossRef]

90. Shah MM, Anderson AE, Leung V, Lin X, Johnston D. Seizureinduced plasticity of $\mathrm{h}$ channels in entorhinal cortical layer III pyramidal neurons. Neuron 2004;44(3):495-508. [CrossRef]

91. Jung S, Jones TD, Lugo JN Jr, Sheerin AH, Miller JW, D'Ambrosio $\mathrm{R}$, et al. Progressive dendritic HCN channelopathy during epileptogenesis in the rat pilocarpine model of epilepsy. J Neurosci 2007;27(47):13012-21. [CrossRef]

92. Shin $M$, Brager D, Jaramillo TC, Johnston D, Chetkovich DM. Mislocalization of $\mathrm{h}$ channel subunits underlies $\mathrm{h}$ channelopathy in temporal lobe epilepsy. Neurobiol Dis. 2008;32(1):2636. [CrossRef]

93. Strauss $\mathrm{U}$, Kole $\mathrm{MH}$, Bräuer AU, Pahnke J, Bajorat R, Rolfs $A$, et al. An impaired neocortical Ih is associated with enhanced excitability and absence epilepsy. Eur J Neurosci 2004;19(11):3048-58. [CrossRef]

94. Schridde U, Strauss U, Bräuer AU, van Luijtelaar G. Environmental manipulations early in development alter seizure activity, Ih and HCN1 protein expression later in life. Eur J Neurosci 2006;23(12):3346-58. [CrossRef]

95. Kuisle $M$, Wanaverbecq $N$, Brewster $A L$, Frère $S G$, Pinault $D$, Baram TZ, et al. Functional stabilization of weakened thalamic pacemaker channel regulation in rat absence epilepsy. J Physiol 2006;575(Pt 1):83-100. [CrossRef]

96. Ludwig A, Budde T, Stieber J, Moosmang S, Wahl C, Holthoff K, et al. Absence epilepsy and sinus dysrhythmia in mice lacking the pacemaker channel HCN2. EMBO J. 2003;22(2):216- 24.

97. Chen K, Aradi I, Thon N, Eghbal-Ahmadi M, Baram TZ, Soltesz I. Persistently modified h-channels after complex febrile seizures convert the seizure-induced enhancement of inhibition to hyperexcitability. Nat Med 2001;7(3):331-7. [CrossRef]

98. Tang B, Sander T, Craven KB, Hempelmann A, Escayg A. Mutation analysis of the hyperpolarization-activated cyclic nucleotide-gated channels HCN1 and HCN2 in idiopathic generalized epilepsy. Neurobiol Dis 2008;29(1):59-70. [CrossRef]

99. Steriade $M$, Nuñez A, Amzica F. A novel slow $(<1 \mathrm{~Hz})$ oscillation of neocortical neurons in vivo: depolarizing and hyperpolarizing components. J Neurosci 1993;13(8):3252-65. [CrossRef]

100. Chung WK, Shin M, Jaramillo TC, Leibel RL, LeDuc CA, Fischer SG, et al. Absence epilepsy in apathetic, a spontaneous mutant mouse lacking the $\mathrm{h}$ channel subunit, HCN2. Neurobiol Dis 2009;33(3):499-508. [CrossRef]

101. Heuermann RJ, Jaramillo TC, Ying SW, Suter BA, Lyman KA, Han $Y$, et al. Reduction of thalamic and cortical th by deletion of TRIP8b produces a mouse model of human absence epilepsy.
Neurobiol Dis 2016;85:81-92. [CrossRef]

102. Reid CA, Phillips AM, Petrou S. HCN channelopathies: pathophysiology in genetic epilepsy and therapeutic implications. Br J Pharmacol 2012;165(1):49-56. [CrossRef]

103. Kole MH, Brauer AU, Stuart GJ. Inherited cortical HCN1 channel loss amplifies dendritic calcium electrogenesis and burst firing in a rat absence epilepsy model. J Physiol 2007;578(Pt 2):507-25. [CrossRef]

104. Samotaeva IS, Tillmanns N, van Luijtelaar G, Vinogradova LV. Intracortical microinjections may cause spreading depression and suppress absence seizures. Neuroscience 2013;230:50-5.

105. Cain SM, Tyson JR, Jones KL, Snutch TP. Thalamocortical neurons display suppressed burst-firing due to an enhanced Ih current in a genetic model of absence epilepsy. Pflugers Arch 2015;467(6):1367-82. [CrossRef]

106. Hughes SW, Cope DW, Crunelli V. Dynamic clamp study of Ih modulation of burst firing and delta oscillations in thalamocortical neurons in vitro. Neuroscience 1998;87(3):541-50.

107. Sitnikova $E$, van Luijtelaar G. Reduction of adrenergic neurotransmission with clonidine aggravates spike-wave seizures and alters activity in the cortex and the thalamus in WAG/Rij rats. Brain Res Bull 2005;64(6):533-40. [CrossRef]

108. Ulrich D. Subthreshold delta-frequency resonance in thalamic reticular neurons. Eur J Neurosci 2014;40(4):2600-7. [CrossRef]

109. Zemankovics R, Káli S, Paulsen O, Freund TF, Hájos N. Differences in subthreshold resonance of hippocampal pyramidal cells and interneurons: the role of $\mathrm{h}$-current and passive membrane characteristics. J Physiol 2010;588(Pt 12):2109-32.

110. Hindriks R, van Putten MJ. Thalamo-cortical mechanisms underlying changes in amplitude and frequency of human alpha oscillations. Neuroimage 2013;70:150-63. [CrossRef]

111. Lannes B, Micheletti G, Vergnes M, Marescaux C, Depaulis A, Warter JM. Relationship between spike-wave discharges and vigilance levels in rats with spontaneous petit mal-like epilepsy. Neurosci Lett 1988;94(1-2):187-91. [CrossRef]

112. Poolos NP. Hyperpolarization-Activated Cyclic NucleotideGated (HCN) Ion Channelopathy in Epilepsy. In: Noebels JL, Avoli M, Rogawski MA, Olsen RW, Delgado-Escueta AV, editors. Jasper's Basic Mechanisms of the Epilepsies. 4th ed. Bethesda: National Center for Biotechnology Information; 2012. p. 109-25.

113. Surges R, Brewster AL, Bender RA, Beck H, Feuerstein TJ, Baram TZ. Regulated expression of HCN channels and CAMP levels shape the properties of the $\mathrm{h}$ current in developing rat hippocampus. Eur J Neurosci 2006;24(1):94-104. [CrossRef]

114. Chen SD, Yeh KH, Huang YH, Shaw FZ. Effect of intracranial administration of ethosuximide in rats with spontaneous or pentylenetetrazol-induced spike-wave discharges. Epilepsia. 2011;52(7):1311-8. [CrossRef] 